\title{
EDYTA STEIN W ROSJI
}

W Sankt Petersburgu bardzo dobrze rozwinięty jest system publicznych wykładów. Otwarte dla szerokiego audytorium wydarzenia odbywają się w znanych publicznych miejscach: uniwersytetach, placówkach oświatowych, muzeach, galeriach sztuki, bibliotekach oraz parafiach. Daje to możliwość dyskusji, pozwala zweryfikować zainteresowanie daną tematyką, to także okazja do spotkań $\mathrm{z}$ „towarzyszami broni”. Osobiście prowadzę cykl otwartych wykładów Kobieta w historii filozofii: rola, tragedia, wykluczenie (Женщина в истории философии: роль, трагедия, исключение) w Muzeum Sztuki Współczesnej Erarta (Музей современного исуксства Эрарта, Sankt Petersburg) ${ }^{1}$. Z okazji moich urodzin, 14 marca 2014 roku wygłosiłam wykład poświęcony Edycie Stein pod tytułem Fenomenologia życia Edyty Stein (Феноменология жизни Эдит Штайн) ${ }^{2}$. Zgromadzona publiczność była zróżnicowana, samemu zaś wystąpieniu towarzyszyły liczne pytania, a także łzy. Wywiązała się ożywiona dyskusja, której patronowała osoba Edyty Stein. Rozmowy te nie zakończyły się wraz z wystąpieniem. Trwały także bowiem w trakcie serii wykładów dla studentów i podczas seminariów. Próby dotarcia do źródeł przyniosły marny efekt, ale poszukiwania książek Edyty Stein oraz informacji na jej temat pozwoliły przeprowadzić analizę zawartości periodyków, środków masowej komunikacji, zbiorów bibliotecz-

\footnotetext{
${ }^{1} \mathrm{http}: / /$ geometria.ru/places/galereya-sovremennogo-iskusstva-erarta/announcements/ 247699 [dostęp: 8.01.2014]

${ }^{2}$ www.erarta.com/ru/calendar/events/detail/210bdcc9-9a30-11e3-8cdc-8920284aa333/ [dostęp: 8.01.2014].
} 
nych oraz przestrzeni medialnej. Rezultaty przeglądu zaprezentowane zostaną poniżej.

Dzieła Edyty Stein wydano na początku drugiego tysiąclecia, w niedużym jak na Rosję nakładzie tysiąca egzemplarzy, i już dawno zniknęły ze sprzedaży. Książka Wiedza Krzyża (Наука Креста) w tłumaczeniu Natalii Bakshy (Наталья Бакши) została wydana wspólnie przez Powszechny Prawosławny Uniwersytet (Общедоступный Православный Университет) założony przez ojca Aleksandra Mena (Александр Мень) oraz Instytut Filozofii, Teologii i Historii im. Świętego Tomasza w Moskwie (Институт философии, теологии и истории Святого Фомы в Москве) w 2007 roku. Śmierć i zmartwychwstanie (Смерть и воскресение) w tłumaczeniu A. Swirskiego (А. Свирский) wydało w 2002 roku w Petersburgu wydawnictwo Ступени. Natomiast książka Kobieta - jej zadanie według natury i łaski (Женщина, её миссия по природе и милости Божией) w tłumaczeniu K. Loszczewskiego ( К. Лощевский) została wydana w Petersburgu przez wydawnictwo Береста w 2004 roku.

Wiedzy Krzyża próżno szukać na półkach księgarni czy w sklepach internetowych, podobnie jak i Śmierci i zmartwychwstania. Książkę Kobieta - jej zadanie wedtug natury i łaski można znaleźć w bibliotece parafialnej Świętej Katarzyny w Sankt Petersburgu na Newskim Prospekcie 32/34.

Edyta Stein pojawia się w kilku kontekstach, a mianowicie akademicko-naukowym, religijno-konfesjonalnym, artystycznym oraz historycznym. Każdy z tych planów zostanie poniżej pokrótce omówiony.

1. Badania akademickie koncentrują się przede wszystkim na fenomenologicznej szkole Edmunda Husserla. Fenomenologia jako metoda naukowa i nurt dwudziestowiecznej filozofii jest obiektem zainteresowania nie tylko $\mathrm{w}$ aspekcie historyczno-filozficznym. Jest ona bowiem nadal aktualna ze względu na to, że idee tworzenia subiektywności z intersubiektywności, zastąpienia podmiotu bezosobową podmiotowością, intencjonalności poznania i pola krzyżowania się sensów - czynią możliwą refleksję nad współczesną tak zwaną fragmentaryczną świadomością indywiduum i zmianami zachodzącymi pod wpływem bombardującego nas potoku informacji. Powszechnie dostępna jest treść artykułu i referatu A.E. Sawina (Chanty-Mansyjsk, Югорский государственный университет) Interpretacja fenomenologi Edmunda Husserla u Edyty Sztejn (Истолкование феноменологической философии Гуссерля у Эдит Штайн) ${ }^{3}$. Referat ten został wygłoszony w maju 2012 roku na konferencji Fides et cogitatus в наследии Эдит Штайн („,Fides et

\footnotetext{
${ }^{3}$ http://www.youtube.com/watch?v=-BR_C_i2wEQ [dostęp: 8.01.2014].
} 
cogitatus w spuściźnie Edyty Stein"). Omawiana jest również etyczna perspektywa filozofii Edyty Stein. W Русском журнале ${ }^{4}$ można zaznajomić się z rozważaniami zaprezentowanymi w artykule Edyta Stein: etyczna pozycja żywego podmiotu (Эдит Шmайн: этическая позиция живого субъекта) autorstwa Tatiany Litwin (Татьяна Литвин), historyka fenomenologii, pracownika Centrum Fenomenologii i Hermeneutyki Petersburskiego Uniwersytetu Państwowego. W artykule podjęta została kwestia odpowiedzialności, rozumianej jako odpowiedź osoby, indywidualny wybór. Problematyka odpowiedzialności za wypowiedziane słowo staje się aktualna we współczesnym świecie panoszącego się szumu technologicznego i wszechobecnej informacji. W Rosji kupowane i cytowane są książki Hannah Arendt ${ }^{5}$ poświęcone problematyce odpowiedzialności indywiduum za wypowiadane słowo i dokonane czyny, a także prace Giorgio Agambena dotyczące etycznego i politycznego znaczeniu Zagłady6. Tak więc w celu wzmocnienia badań nad etyką praca nad dziełem Edyty Stein byłaby jak najbardziej pożądana. W filozoficznym zwrocie zauważalne jest zapotrzebowanie na teksty poświęcone problematyce cielesności jako koncepcji wykraczającej daleko poza biologicznie rozumiane ciało. Podejmowanie i rozwijanie Husserlowskich rozważań dotyczących Korper i Leib w aspekcie formującej się podmiotowości jest zatem jak najbardziej aktualne. Powoływanie się na Jeana-Paula Sartre'a i jego „obraz Pierre'a"7, który jest podobny do samego Pierre'a, czy też na Maurica Merleau-Pontey'ego z jego wypaczeniem kartezjanizmu8 stały się klasycznymi wątkami obecnymi u osób broniących dysertacje z zakresu badania ciała jako konstruktu świadomości i cielesności jako rozszerzającej się granicy podmiotowości. Fenomenologiczna percepcja i społeczne uwarunkowania ciała, rozpatrywane przez Edytę Stein, rozszerzyłyby horyzont badań i dopełniłyby perspektywę postrzegania dwudziestowiecznej filozofii. Także w mojej książce Maska jako forma tożsamości $i^{9}$ koncept ciała i wizerunku jako konstruktów świadomości rozpatruję z perspektywy fe-

${ }^{4}$ http://www.russ.ru/pole/Edit-SHtajn-eticheskaya-poziciya-zhivogo-sub-ekta [dostęp: 8.01.2014].

${ }^{5} \mathrm{H}$. Arendt, Eichmann w Jerozolimie: rzecz o banalności zła, tłum. A. Szostkiewicz, Kraków 1998; taż, Odpowiedzialność i władza sądzenia, tłum. W. Madej, M. Godyń, Warszawa 2006.

${ }^{6}$ G. Agamben, Homo sacer: suwerenna władza i nagie życie, tłum. M. Salwa, Warszawa 2008; tenże, Co zostaje z Auschwitz: archiwum i świadek, tłum. S. Królak, Warszawa 2008.

7 J.-P. Sartre, Wyobrażenie: fenomenologiczna władza wyobraźni, tłum. P. Beylin. Warszawa 2012.

8 M. Merleau-Ponty, Fenomenologia percepcji, tłum. M. Kowalska, J. Migasiński, Warszawa 2001.

9 О.А. Штайн Маска как форма идентичности. Санкт-Петербург: РХГА, 2012, 2013. http://www.svoboda.org/content/article/24892335.html [dostęp: 9.01.2014]. 
nomenologicznej, zaś w trzecim wydaniu tejże książki metodologię przeformułuję tak, by uwzględniała ona komentarze Edyty Stein.

2. Perspektywa feministyczna. W artykule Konstruowany artefakt czy cielesna, transcendująca przyrodę istota?, napisanym przez Hannę-Barbarę GerlFalkovitz jako posłowie do książki Kobieta - jej zadanie według natury i łaski, zaobserwować można nakładanie się na siebie pola fenomenologicznego i feministycznego. Tekst daje możliwość postawienia serii pytań rozciągających się od fenomenologicznego określenia bycia kobiety, aż po badania z perspektywy genderowej, prowadzone w kontekście nieobecności ciała i dekonstrukcji cielesności. Należy zaznaczyć, że w rosyjskim polu badawczym problematyka istoty kobiety zazwyczaj związana jest rozważaniami Simone de Beauvoir, której filozofii w żadnym wypadku nie ogranicza się genderową perspektywą. W Rosji powszechnie dostępna jest książka Edyta Stein. Filozof. Feministka. Święta autorstwa Fredy Mary Oben, w której połączenie "feministka” i „święta” mierzi tradycyjną, prawosławną mentalność rosyjskiego człowieka. Książkę tę wydano dwanaście lat temu w Moskwie przez wydawnictwo «Истина и жизнь», obecnie jest dostępna w wersji online na stronie Livejournal ${ }^{10}$.

3. Sztuka. Osoba Edyty Stein pojawia się także w kontekście sztuki. Poświęcony świętej pomnik w Kolonii dłuta Berta Gerresheima często przywołuje się $\mathrm{w}$ roli ilustracji dla wzniosłej i dogłębnie analizowanej idei dochodzenia do prawdy. Wieloaspektowość dzieła poraża, a narracja wpisana w kamień zdaje się wizualną opowieścią o heroicznym trudzie świętej. Jeśli chodzi o literaturę piękną, to przywołać można prozatorską twórczość Marka Nowickiego, a konkretnie jego książkę Zwyczajna święta, pamięci Edyty Stein (Обыкновенная святая, Эдит Штайн посъящается) ${ }^{11}$, gdzie pisze on o Głosie Bożym, który słyszymy poprzez Edytę Stein. Książkę przeczytać można na rosyjskim serwerze wolnych publikacji Проза.py.

4. Dzięki serwisom informacyjnym możemy dowiedzieć się, że w Austrii odbyła się konferencja poświęcona Edycie Stein (portal Христиане.info), czy też o tym, że w Buenos Aires wystawiono spektakl o filozofce z główną rolą Lili Grinberg, a dla Argentyny jej osoba stanowi przykład jeszcze jednej kobiety, która walczyła o to, w co wierzyła.

\footnotetext{
${ }^{10}$ http:/ / timur0.livejournal.com/63741.html [dostęp: 9.01.2014].

${ }^{11}$ Новицкий М. Обыкновенная святая, Эдит Штайн посвящается. //http:// www.proza.ru/2008/07/30/426 [dostęp: 9.01.2014].
} 
5. Na koniec przejdę do najważniejszego, tego, co najbardziej porusza, o czym pisano najwięcej, czyli do samej osoby świętej Edyty Stein. Na stronie Rzymskokatolickiej Archidiecezji Matki Boskiej w Moskwie można przeczytać bogatą w informacje opowieść Anny Kudrik o życiu filozofki ${ }^{12}$. O czynach świętej piszą także prawosławni popi. Dla przykładu można przywołać choćby znany artykuł ojca Georigija Chistyakova Edyta Stein: tajemnica wiary (Эдит Штайн: тайна веры) ${ }^{13}$. W czytelni biblioteki parafialnej Świętej Katarzyny w Sankt Petersburgu dostępna jest książka Anotnio Sikariego Portery Świętych (Портреты съятых), wydana na licencji wydawnictwa Jaca Book Milano, do którego należą prawa autorskie ${ }^{14}$. Pośród postaci Franciszka z Asyżu, Tomasza Morusa czy Camillo de Lellisa przejmująco opisane zostaje życie i wiara Edyty Stein: jej zwrócenie się od filozofii w stronę wiary. W Rosji odbywają się Lektury Franciszkańskie (Францисканские чтения) i wydawany jest zbiór Święty Franciszek w Rosji (Святой Франциск и Россия) ${ }^{15}$. Uważam, że istnieje potrzeba organizowania podobnych konferencji i wydawania monografii jeśli chodzi o Edytę Stein. Druga książka, o której warto wspomnieć, a którą przedłożyła mi do lektury Marina Melka z parafii Świętej Katarzyny, nosi tytuł Realizm świętości (Peanuзм сьятости $)^{16}$. Dzieło to opowiada o trzech kobietach, które w czasie drugiej wojny światowej były ofiarami nazistowskich obozów zagłady. Były to: matka Maria mniszka, Ludmila Dedjuhina, święta mniszka, oraz Teresa Benedykta od Krzyża (Edyta Stein). Edycie Stein poświęcony został rozdział Edyta Stein - nowa chrześcijańska święta, w której opowiada się między innymi o jej rodzinie, okresie ateistycznym, okresie fenomenologicznym - rozdział Fascynacja Husserlem (Очарования Гуссерля) - tłumaczeniach Tomasza z Akwinu. Rozdział napisany został przez Ferdinanda Schlickela, a przetłumaczyła go W.K. Abalakina. W książce zamieszczony jest również tekst Edyty Stein Jak wstapiłam do Karmelu w Kolonii.

Wszystko, co wiąże się z Edytą Stein, zdaje się przejmującym i natchnionym. W wygłoszonym przeze mnie wykładzie wykorzystałam prezentacje biografii Edyty Stein zaprezentowaną i udostępniona dla widzów w 2012

12 http:/ / www.cathmos.ru/content/ru/publication-2011-07-25-12-50-06.html [dostęp: 9.01.2014]

${ }^{13} \mathrm{http}: / /$ tapirr.com/ekklesia/chistyakov/vechn_grad/edit_stayn.htm [dostęp: 9.01.2014].

${ }^{14}$ Editoriale Jaca Book spa, Milano «RITRATTI DI SANTI»

15 Святой Франциск и Россия. Санкт-Петербург: Российско-итальянский фонд «Диалог культур», РХГА.

16 Реализм святости. Мать Мария, Людмила, Эдит Штайн. Сборник./ Составитель О.Т. Ковалевская. Санкт-Петербург: Проспект, 2000. 
roku przez Bibliotekę i Centrum kulturowe Inigo (Иниго)17. Jasne, piękne oblicze Edyty Stein otwiera się w każdym, kto zetknął się z jej osobą, historią, wiarą. Być może skromność tego przeglądu, która wynika z ilości informacji, jakie są dostępne w Rosji na temat Świętej, będzie zachętą do dalszego propagowania i zgłębiania życia i filozofii Edyty Stein.

Z języka rosyjskiego przełożyła Olga Aroniewicz

\section{Edith Stein in Russia}

\section{Summary}

In this article a reception of Edith Stein's philosophy in Russian academic, religious, artistic and medial discourses is presented. The author discusses scholarly elaborations devoted to Stein, her presence in media, libraries and on the Internet. Then, the author analyses the actual state of research, notably feministic and gender approaches, as well as the issue of corporeality, artistic works devoted to Stein and the contents of information services and websites.

17 Prezentacja powstała w związku z konferencją „Fides et cogitatus. в наследии Эдит ШтайH”, która odbyła się w maju 2012 roku: http://www.people.su/youtube_video-biografiyaehdit-shtajjn [dostęp: 9.01.2014]. 